\title{
Local wheat peel as a solid surface to remove Azure B dye from aqueous solution:Equilibrium isotherms and thermodynamic study
}

\author{
Saja S. Al-Taweel* Nawal K. Jabbar* \\ Ahmed J. Auda* \\ Rana S. Al-Taweel** \\ *Department of Chemistry, College of Science, University of Al-Qadisiya, Dewaniya, \\ Iraq \\ ** Department of Biology, College of Education, University of Al-Qadisiya, \\ Dewaniya, Iraq \\ E-mail: sajataweel@yahoo.com
}

Received 21/9/2015

Accepted 20/12 /2015

(1) 9

This work is licensed under a Creative Commons Attribution-NonCommercialNoDerivatives 4.0 International Licens

\begin{abstract}
:
In this research local wheat peel was used as an adsorbent surface for removal of Azure B (AB) dye from the aqueous solution. The adsorption process was performed at different experimental parameters, equilibrium time, temperature, ionic strength and solution $\mathrm{pH}$. The isotherms of adsorption are of H-type as compared with Giles curves and the adsorption data were coincide with Freundlich equation. The adsorption kinetic data were analyzed using pseudo- first and second order kinetic models. The effect of temperature was studied and the amount of dye adsorbed was found to increase with the increasing of temperature from 25 to $50{ }^{\circ} \mathrm{C}$. The values of thermodynamic functions like enthalpy and entropy have been estimated. The quantity of adsorbed dye on the wheat peel increase according to the sequence follows: $\mathrm{pH}$ $9.3>8>7>6>5$.2. The adsorption phenomenon is influenced by the sodium chloride concentration of solution. The obtained data refer to a decrease in amount of Azure B adsorbed in the existence of electrolyte.
\end{abstract}

Key words: wheat peel, Azure B, adsorption equilibrium, thermodynamics.

\section{Introduction}

The pollution of the water is known to the changes in its chemical, biological and physical properties that which may be effect the organisms life. The contamination of water is occur when materials and energy are released to the water sources, and this cause in degrading the nature and purity of the water that use in different kinds of users. It implicates every of the contaminant materials which is not destroyed by the water naturally [1]. There are much of the several types of methods may be physical or chemical that were used widely for the treatment of the contaminated of water, one of these 
methods is change of phase, the separation of gravity, the processes of oxidation or the reduction, ion exchange of the ions of water and adsorption[2].Adsorption can be defined is the phenomenon in which the atoms of the matter or the ions of this matter and may be the molecules which accumulate on the surface of another solid material by different kinds of binding forces, it's usually can be used as a economical method to treat the pollution of water and to remove the toxically soluble compounds that may be in any kind, organic or inorganic materials [3]. One of the most popular organic compounds are dyes, which are excessively used in various types of industries like industry of plastic, leaf, textiles, dwelling and fur dyeing[4,5]. "The discharge of the effluents of textile manufacture that which contain high colored into the water sources makes the nature of water was not suitable to use in domestic, industrial and the processes of agricultural"[6]. Usually the most dyes used in the textile are of highly toxicity to the human and animal cells and may cause cancer, mutagen of the cells and teratogenicity effect on the health of human and animal [4,7]. Literatures recorded a common use of technique of adsorption to treat the wastewater inflow from the textile factories using activated charcoal prepared from various agricultural plants[8],metals of clay[9] and variety types of wastes agricultural such as , rice peel[10], saw dust[11], bean husk[12], pistachio shell[13],etc.

In this research the ability to use the waste of agricultural, wheat peel, as a cheap surface to remove the Azure B dye from waste water was investigated in different experimental factors of $\mathrm{pH}$ temperature, and the ionic strength of solution. The equilibrium data were analyzed in terms of thermodynamic functions of adsorption process.

\section{Materials and Methods:} Preparation Solutions of Dye

The azure B was purchased from sigma company; the chemical formula of this dye was seen in Scheme (1).<smiles>C[N+]=c1ccc2nc3ccc(N(C)C)cc3sc-2c1</smiles>

Scheme (1). The chemical formula of the Azure B dye

The wavelength at maximum absorbence $(\chi \max )$ was estimated for Azure B and was found to be $646 \mathrm{~nm}$. The concentration of dye at equilibrium was determined at this wavelength value. The dye solution was prepared with different concentration and the absorbance quantity of these diluted dye solutions at the $646 \mathrm{~nm}$ was draw versus the values of concentration. The applicability of Beer- Lambert's was verified from the straight line of the plot.

\section{The preparation of solid surface}

To remove the dust and other polluted materials that may affect the properties of the solid surface, the wheat peel was cleaned by washing with distilled water for more than one time. The washing surface was then left to dry for $1.5 \mathrm{hr}$ in an oven at $120^{\circ} \mathrm{C}$, and kept until using in a container. The surface in powder form was sieved to get a size of particle $150 \mu \mathrm{m}$ and this particle grain was used to performed the adsorption experiments.

\section{Effect of Equilibrium Time}

The kinetic of dye adsorption was performed by using $0.1 \mathrm{~g}$ of surface with $10 \mathrm{ml}$ of fixed concentration of dye solution $(60 \mathrm{ppm})$. The suspensions were centrifuged at different times and the equilibrium dye concentration was estimated by the UV-Vis spectroscopy (Shimadzu.PC1650,Japan). 


\section{Adsorption Isotherm}

The ten $\mathrm{ml}$ of the solutions of $\mathrm{AB}$ dye of varies concentrations were mixed with the weight of $0.1 \mathrm{~g}$ of wheat peel surface in stopper flasks. The flasks were put in water bath controlled by the temperature thermostat at $25^{\circ} \mathrm{C}$ (shaking bath type Scientific K\&K, Korea) until the adsorption process is attained equilibrium (90 min).then, the suspension solutions were centrifuged for $10 \mathrm{~min}$ at $3000 \mathrm{rpm}$. The equilibrium concentration of dye was determined from the calibration plot of $\mathrm{AB}$ dye.

The equation used to calculated the amount of the dye adsorbed is[14]:$q_{\mathrm{e}}=\left(\mathrm{C}_{0}-\mathrm{C}_{\mathrm{e}}\right) \mathrm{V} / \mathrm{m}$

Where $\mathrm{C}_{\mathrm{o}}, \mathrm{C}_{\mathrm{e}}$ are the initial concentration and the equilibrium concentration of $\mathrm{AB}$ dye $(\mathrm{mg} / \mathrm{L}) . \mathrm{m}$ is the weight of wheat peel surface $(\mathrm{g})$ and $\mathrm{V}$ is the volume solution of the $\mathrm{AB}$ dye (L).

\section{Temperature Effect}

The effect of temperature on the amount of dye removal was studied at $25, \quad 35$ and $50^{\circ} \mathrm{C}$ to estimate the enthalpy, entropy and Gibbs free energy of removal process.

\section{Electrolyte Effect}

The solution of knowing concentration of the $\mathrm{AB}$ dye and sodium chloride with various weight of $(0.05-$ $0.3 \mathrm{~g}$ ) were mixed with $0.1 \mathrm{~g}$ of wheat peel surface in a conical flask. The adsorption experiment was performed to obtain the amount of $\mathrm{AB}$ dye removed by the adsorbent in the presence of electrolyte.

\section{Initial pH Effect}

The effect of the $\mathrm{pH}$ on the adsorption process can be followed by the use of the solutions of dye with known concentration and varied $\mathrm{pH}$ (5.2-9.3). $0.1 \mathrm{M}$ hydrochloric acid and $0.1 \mathrm{M}$ of sodium hydroxide that were used to adjust the acidic function of the dye solution.

\section{Results and Discussion:}

The removal of $A B$ dye from the solution by wheat peel surface was determined at $25^{\circ} \mathrm{C}$ and at higher temperatures at $\left(35\right.$ and $\left.50^{\circ} \mathrm{C}\right)$ with the $\mathrm{pH}$ of solution 6 .

The equilibrium isotherm for adsorption of dye was indicated in Figure (1), the amount of dye adsorbed on the biosorbent surface was plotted against the concentration of equilibrium at $25^{\circ} \mathrm{C}$.

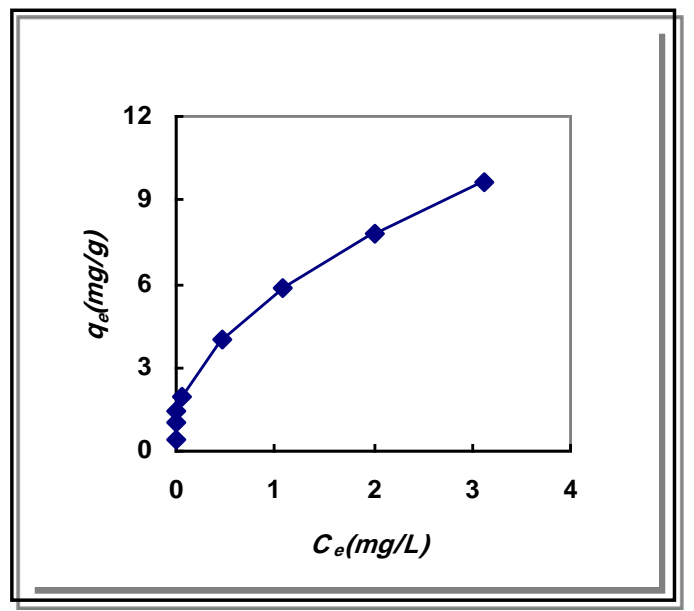

Fig.(1). The isotherm curve of $\mathrm{AB}$ dye on wheat peal at $25^{\circ} \mathrm{C}$

As appear from the results, the capacity of the surface of wheat peel increase as the increasing of concentration of $\mathrm{AB}$ dye. The physicochemical properties of the wheat peel as a kind of agricultural plants consist of different functional groups, fibers of abundant floristic, and series of proteins that make the adsorption process occur easily[15].

As reported by Giles et al,[16] the isotherms of $\mathrm{AB}$ dye were found to take shape of $\mathrm{H}$-curve. The $\mathrm{H}$-curve refer to the more affinity between the structure of dye and surface of the solid adsorbent.

The equilibrium of removal process of dye can be determined by applying the experimental equation Freundlich [17]:

$$
\mathrm{q}_{\mathrm{e}}=\mathrm{kC}_{\mathrm{e}} \mathrm{e}^{1 / \mathrm{n}}
$$


$\mathrm{q}_{\mathrm{e}}(\mathrm{mg} / \mathrm{g})$ is the amount of dye adsorbed. $C_{e}(\mathrm{mg} / \mathrm{L})$ is the concentration of dye at equilibrium, $n$ and $k$ are constants that expressed the affinity and capacity of adsorption process.

The linear from of the above equation is: $\log \mathrm{q}_{\mathrm{e}}=\log \mathrm{k}+1 / \mathrm{n} \log \mathrm{C}_{\mathrm{e}}$

The relationship between $\log q_{e}$ and $\log$ $C_{e}$ of Freundlich equation was given in Figure (2). The magnitudes of correlation coefficient and the Freundlich parameters was determined $\left(r^{2}=0.985, \quad n=2.68, \quad k=10^{0.77}\right)$. The applicability of Freundlich equation to the experimental data, refer to the physical adsorption of $\mathrm{AB}$ dye on the biosorbent surface. The high $\mathrm{n}$ value, indicate the higher affinity between the components of adsorption system.

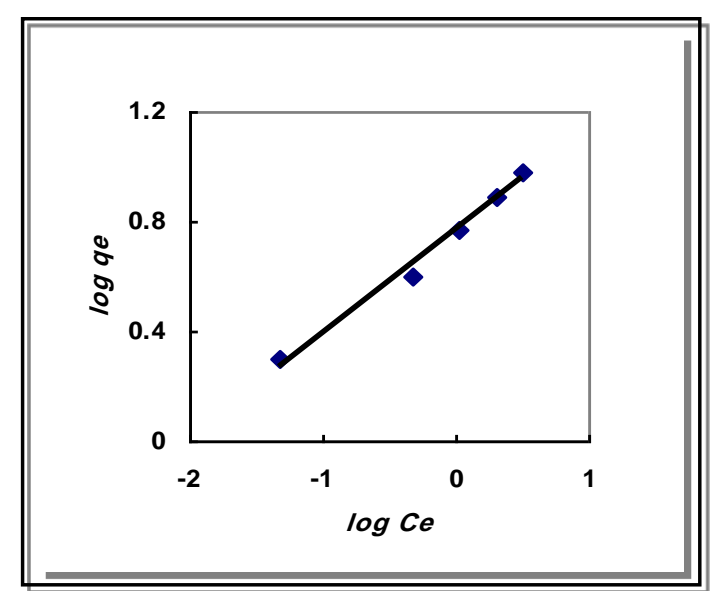

Fig.(2): plot of Freundlich isotherm of the $A B$ dye -wheat peel system

The shapes of adsorption isotherms of $\mathrm{AB}$ dye was recorded at various temperatures as shown in Figure (3).

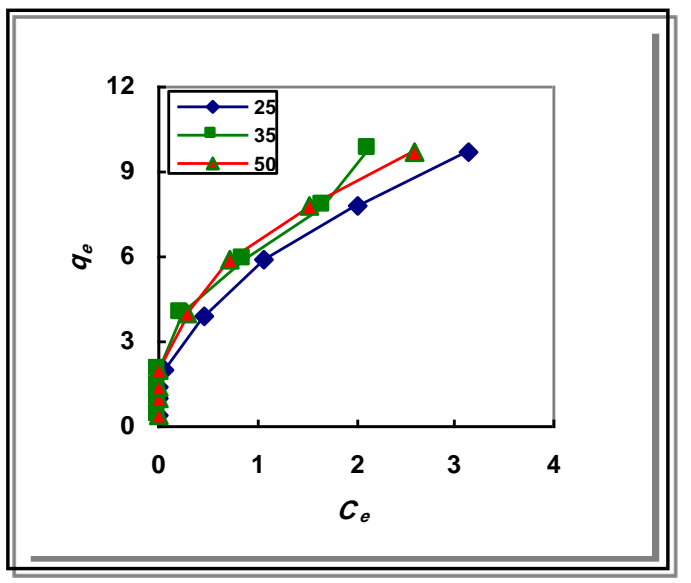

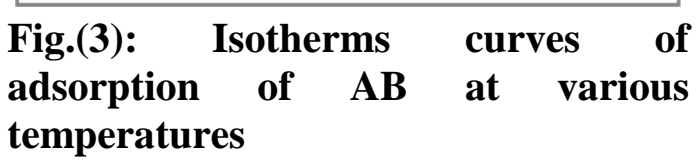

The obtained data indicated an increased in the quantity of $\mathrm{AB}$ dye attached to the surface with raising the temperature from the $25^{\circ} \mathrm{C}$ to $50^{\circ} \mathrm{C}$; so the process of adsorption from the view of thermodynamic is endothermic process. It was found that the amount of adsorption of few dye systems was increase with raising in the temperature. The endothermic nature of adsorption may be due to the combination of absorption and adsorption processes in the reaction system [18].

The enthalpy of adsorption $\left(\Delta \mathrm{H}^{\mathrm{o}}\right)$ was determined from Van't Hoff equation: $\ln \mathrm{Xm}=-\Delta \mathrm{H} / \mathrm{R}+$ const., the free energy change $\left(\Delta G^{\circ}\right)$ was estimated as in the following equation: $\left(\Delta \mathrm{G}^{\mathrm{o}}=-\mathrm{RT} \ln \mathrm{K}\right)$ and the Gibbs equation was used to calculate the entropy change of adsorption system $\left(\Delta \mathrm{S}^{\mathrm{O}}\right)$ :

$\Delta \mathrm{G}^{\mathrm{o}}=\Delta \mathrm{H}^{\mathrm{o}}-\mathrm{T} \Delta \mathrm{S}^{\mathrm{O}}$ 


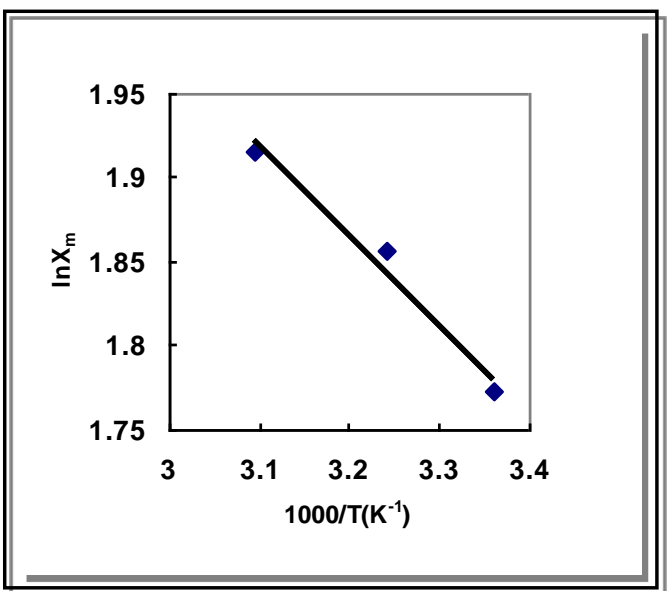

Fig.(4): Plot of maximum adsorption capacity versus reciprocal temperature (K)

The Table (1) appeared the values of the thermodynamic of adhesion process of dye to the surface. The van der Waals bonding is the common forces that controls the attachment process.

Table (1): the calculations of thermodynamic functions of the process of adsorption

\begin{tabular}{|c|c|c|}
\hline $\begin{array}{c}\Delta H^{o} \\
k J . m o I^{I}\end{array}$ & $\begin{array}{c}\Delta S^{o} \\
\operatorname{J}^{\prime} I^{1} \cdot k^{-1}\end{array}$ & $\begin{array}{c}\Delta G^{o} \\
k^{\prime} . m o I^{I}\end{array}$ \\
\hline+4.447 & +48.270 & -9.937 \\
\hline
\end{tabular}

The positive enthalpy value $\left(\Delta \mathrm{H}^{0}\right)$ and the negative free energy $\operatorname{value}\left(\Delta \mathrm{G}^{\mathrm{o}}\right)$ indicated that $\mathrm{AB}$ dye-wheat peel adsorption system is occur spontaneously with endothermic nature. In addition the adsorption process of dye is in accompanied with the increase in randomity of the system.

Figure (5) showed that adsorption of dye on wheat peel was slightly affected by $\mathrm{pH}$ solution.

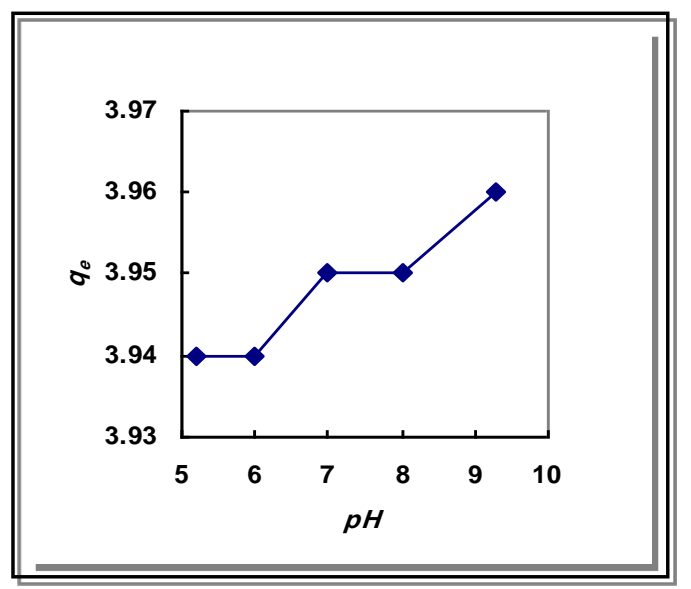

Fig.(5): The effect of $\mathrm{pH}$ solution on adsorption of $\mathrm{AB}$ dye on wheat peel at $25^{\circ} \mathrm{C}$

The soluble $\mathrm{AB}$ dye take the cationic form in the aqueous solution, so that in the minimum $\mathrm{pH}$ the forces of repulsion between charge with the positive sign of the wheat peel surface and the positive charges of the functional groups of dye may be dominant.

The effect of electrolyte concentration on the adsorption of $\mathrm{AB}$ dye by wheat peel was demonstrated at six weights of the salt of sodium chloride $(0.05-0.3 \mathrm{~g})$. As shown from Figure (6), the effect of the concentration of electrolyte on the amount of $\mathrm{AB}$ dye adsorbed on the biosorbent surface.

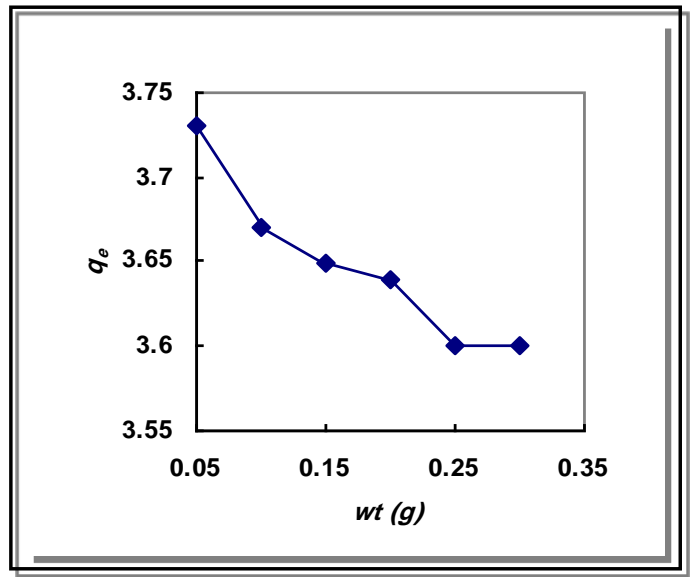

Fig.(6):The effect of electrolyte concentration on the amount of $\mathrm{AB}$ dye adsorption

The extent of adsorption was decreased in the existence of sodium chloride. This 
result can be refer to that hydrated cations (sodium positive ions and the cationic groups of dye) compete to adsorbed on the active sites of the solid surface[19].

Figure (7) indicates the change in removal percent of the $\mathrm{AB}$ with the time. At the initial stages of adsorption process, the percent of dye removal is change linearly with the time; which refers to that more active sites presence on the surface of the wheat peel.

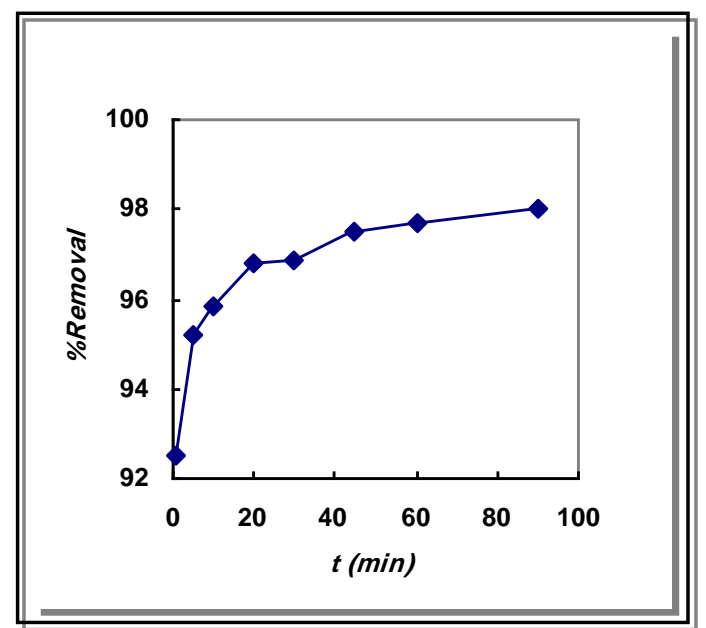

Fig.(7): The change in removal percent of $\mathrm{AB}$ dye with the time at $25^{\circ} \mathrm{C}$

The analysis of the kinetic of adsorption reaction was demonstrated by the pseudo-first order and pseudosecond order kinetic equations, the linear equation of the first order kinetic[20] is:

$\ln \left(q_{e}-q_{t}\right)=\ln q_{e}-k_{1} t$

Where $q_{t}$ and $q_{e}$ are the amounts of adsorption (mg dye/gm of adsorbent) at time $t$ and at equilibrium ( $\mathrm{min}$ ), respectively. The slope of plot of the above equation (Figure (8)) was used to determine the value of rate constant $\left(\mathrm{k}_{1}\right)$.

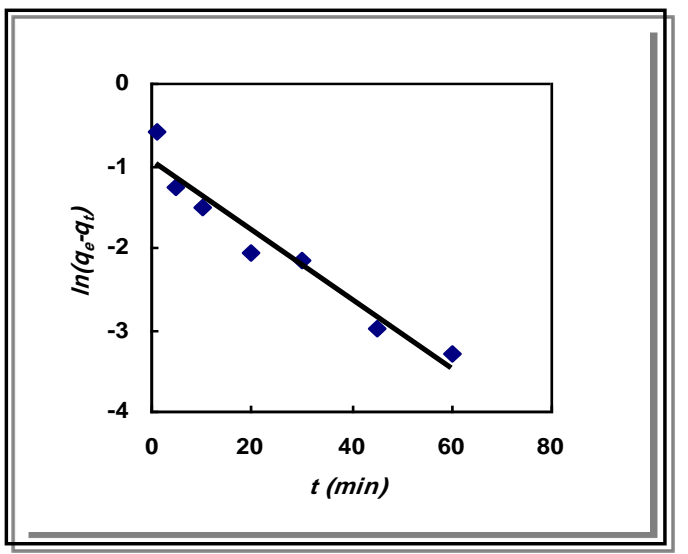

Fig.(8): The first order kinetic curve of dye adsorption

The linear kinetic equation of pseudo second order [21] is:

$t / q_{t}=1 / h+\left(1 / q_{e}\right) t$

The initial rate of adsorption is $h$ and was equal to: $h=k_{2} q_{e}^{2}, k_{2}$ is the rate constant of pseudo-second order. The straight line of the curve $t / q_{t}$ against $t$ was given in Figure (9) and the constants of pseudo-second order can be calculated.

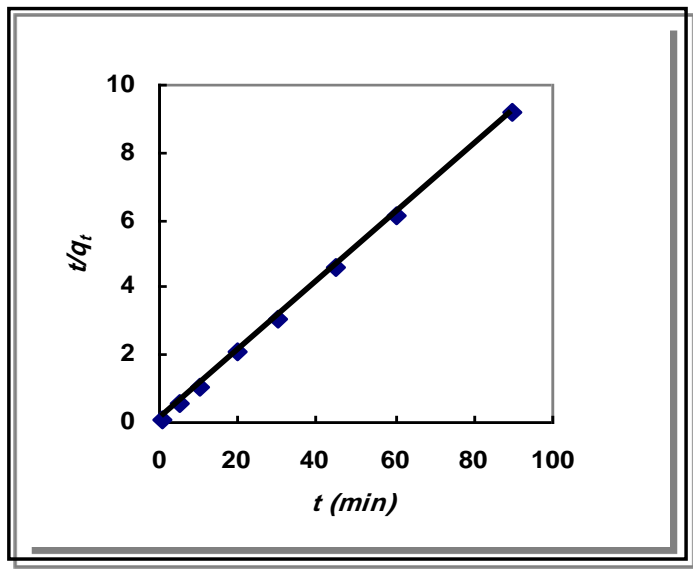

Fig.(9):The pseudo-second order curve of dye adsorption system

The kinetic constants for the attachment of dye are indicated in Table (3). As appered from the values of theoretical qe and the correlation coefficient of the curve, the experimental data was good demonstrate with the second order equation as compared with that of first order equation.

Table(2): Kinetic constants for the adsorption system of ABdye

\begin{tabular}{|c|c|c|c|c|c|c|}
\hline \multicolumn{3}{|c|}{ Pseudo-first order equation } & \multicolumn{4}{|c|}{ Pseudo-second order equation } \\
\hline$k_{l}\left(\mathrm{~min}^{-1}\right)$ & $q_{e}(\mathrm{mg} / \mathrm{g})$ & $r^{2}$ & $k_{2}\left(\mathrm{~g} \cdot \mathrm{mg}^{-1} \cdot \mathrm{min}^{-1}\right)$ & $q_{e}(\mathrm{mg} / \mathrm{g})$ & $\mathrm{h}\left(\mathrm{mg} \cdot \mathrm{g}^{-1} \cdot \mathrm{min}^{-1}\right)$ & $I^{2}$ \\
\hline 0.0420 & 0.3890 & 0.9400 & 0.4650 & 9.8130 & 44.8400 & 1.000 \\
\hline
\end{tabular}




\section{Conclusions:}

Chaff biosorbent has high capacity for removal of Azure B from solution.

-The isotherms of adsorption of Azure B dye obeyed Freundlich model.

-Azure B-wheat peel interaction give positive and low value of enthalpy (endothermic adsorption system).

-The adsorption of Azure B dye on the surface is influence by the $\mathrm{pH}$ of dye solution.

-The extent of adsorption of Azure B dye decrease with the increasing of electrolyte concentration in solution.

-The kinetic of removal of Azure B dye is demonstrate by pseudo second-order equation.

\section{References:}

[1]Makay, G.; Blair, H. S. and Gardner, J. R. 1982. Adsorption of dyes on chitin, I: equilibrium studies, J. Appl. Polym. Sci. 29:3043-3057.

[2]Turkar, S. S.; Bharti, D. B.and Gaikwad, G. S. 2011.Various methods involved in waste water treatment to control water pollution, J. Chem. Pharm. Res.,3 :58-65.

[3] Rengaraj, S.; Seuny-Hyeon, M; and Sivabalan, R. 2002. Agricultural solid waste for the removal of organics: adsorption of phenol from water and wastewater by Palm seed coat activated carbon, Waste Management, 22 :543-548.

[4]Indra, D.M.; Vimal, C.S.; Nitin, K.A. and Indra, M. M. 2005. Adsorptive removal of malachite green dye from aqueous solution by bagasse fly ash and activated carbon-kinetic study and equilibrium isotherm analyses. Colloid and Surface, 264:17-28.

[5] Gharbani, P.; Tabatabaii, S.M. and Mehrizad A. 2008. Removal of Congo red from textile wastewater by ozonation., Int. J. Environ. Sci. Tech., 5:495-500.

[6] Baughman, G. and Perenich T. A.1988. Fate of dyes in aquatic systems: I. Solubility and partitioning of some hydrophobic dyes and related compounds., Environ. Toxicol. Chem., 7:183-199.

[7] Sabnis, R.E. 2010. "Handbook of Biological Dyes and Stains", John Wiley \& Sons, New York, pp:106,239.

[8] Demiral, H.; Karabacakoğlu, B. and Tümsek, F. 2008. Adsorption of Textile Dye onto Activated Carbon Prepared from Industrial Waste by $\mathrm{ZnCl} 2$ Activation, J. Int. Environ. Appl. \& Sci., 3:381-389.

[9] Jayalakshmi, L.; Devadoss, V.; Ananthakumar, K. and Kanthimathi, G. 2014. Adsorption Efficiency of Natural Clay towards the Removal of Naphthol Green Dye from the Aqueous Solution: Equilibrium and Kinetic Studies, Int. Res. J. Environ. Sci., 3: 21-26.

[10] Sivakumar, V. M.; Thirumarimurugan, M.; Xavier, A. M.; Sivalingam, A. and Kannadasan, T., 2012. Colour Removal of Direct Red Dye Effluent by Adsorption Process Using Rice Husk, In.t. J. of Biosci., Biochem. and Bioinform., 2 :377-380.

[11] Hameed, B. H.; Ahmad, AL and Latiff, KNA. 2007. Adsorption of basic dye (methylene blue) onto activated carbon prepared from rattan sawdust ,Dyes Pigment, 75:143-149.

[12] Hameed, BH. and El-Khaiary, MI. 2008. Sorption kinetics and isotherm studies of a cationic dye using agricultural waste: broad bean peels, J. Hazard Mater. ,154:639-664.

[13] Choudhury, T. R.; Amin, M. N.; Quraishi, S. B. and Mustafa A. I. 2014. Adsorption, desorption and kinetic study on hexavalent chromium removal from aqueous solution using groundnut shell, Res. J. Eng. \& Appl. Sci.,3 :1-6.

[14]Voyutsky, S. 1978. Colloid Chemistry, Mir Publishers, Moscow, p.452. 
[15] Han, R.P.; Yin, J.S.;Li, H.Q.; Li, Y.H.; Wu, Y.J. and Shi, J. 2004. Analysis and Comparison of Infrared Spectra of Native Cereal Chaff and Pyrolysis Products, Spectrosc. Spect. Anal., 24:187-188.

[16] Giles, C. H.; Macewan, T. H.; Nakhwa, S.N. and Smith, D. J. 1960. A system of classification of solution adsorption isotherms, and its use in diagnosis of adsorption mechanisms and in measurement of specific surface area of solids, Chem. Soc., 786:3973-3993.

[17] Xunjun, C. 2015. Modeling of Experimental Adsorption Isotherm Data , Information, 6:14-22.

[18] Min, L.U; Yue-ming, Z.; Xiao-hui, G.; Xiao-hui, XU. and Ting-ting, GAO. 2014. Thermodynamics and kinetics of adsorption for heavy metal ions from aqueous solutions onto surface amino-bacterial cellulose, Trans. Nonferrous Met. Soc. China, 24:1912-1917.

[19] Bouatay, F.; Dridi, S. and Mhenni, M.F. 2014. Valorization of Tunisian Pottery Clay onto Basic Dyes Adsorption, Int. J. Environ. Res., 8 :1053-1066.

[20] Namasivayma, C. and Kanchana, N. 1992. Waste banan pith as adsorbent for colour removal from wastewater, Chemosphere, 25:16911705.

[21] Laowansiri, S. 2011. Kinetic and efficiency of reactive dye sorption by plant biomass, Res.J.of Appl.Sci., 6:15-19.

\section{قشور الحنطة المحلية سطح صلب لازالة صبغة الازور B من محلولها المائي : دراسة التوازن والثرموديناميك
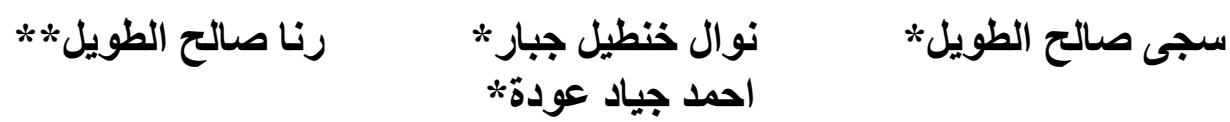

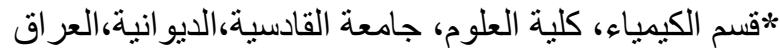

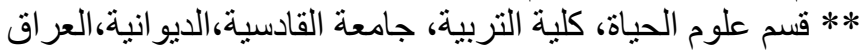

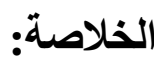

يتضمن البحث الحالي دراسة مدى فعالية سطح قثتور الحنطة لامتز از صبغة الازور B من المحلول

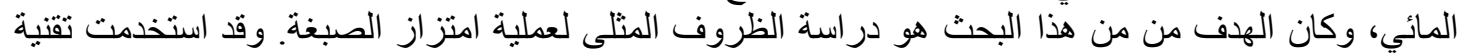

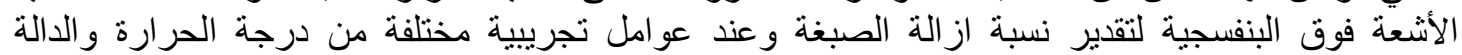

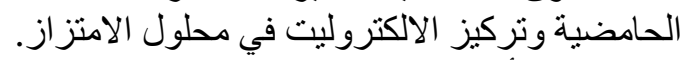

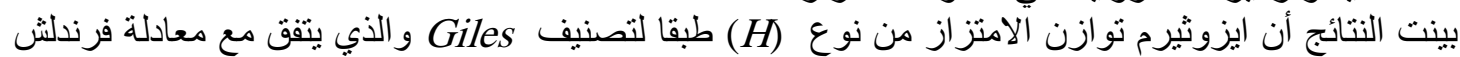

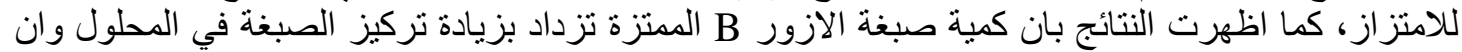

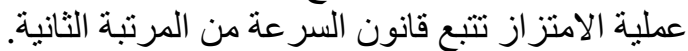

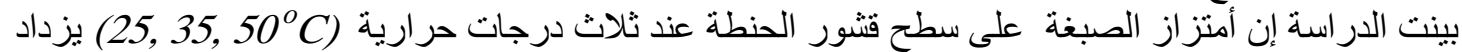

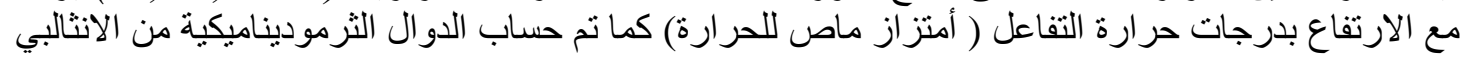

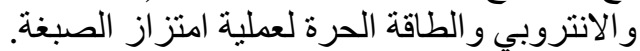

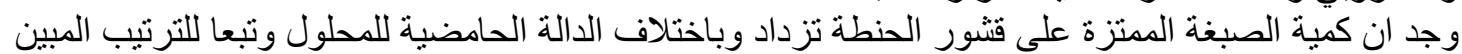

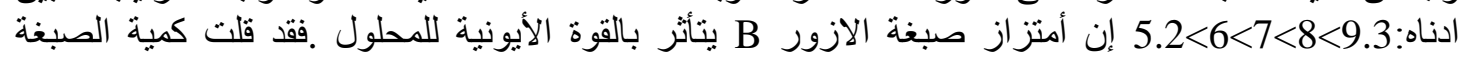

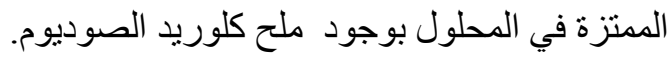
الكلمات المفتاحية: قتشور الحنطة، الازور B ، توازن الامتز از ، ثرموديناميك.
} 